\title{
Lesser Prairie-Chicken Space Use in Relation to Anthropogenic Structures
}

\author{
REID T. PLUMB, ${ }^{\mathbf{1 , 2}}$ Kansas State University, 212 Leasure Hall, Manhattan, KS 66506, USA \\ JOSEPH M. LAUTENBACH, ${ }^{3}$ Kansas State University, 212 Leasure Hall, Manhattan, KS 66506, USA \\ SAMANTHA G. ROBINSON, ${ }^{4}$ Kansas State University, 212 Leasure Hall, Manhattan, KS 66506, USA \\ DAVID A. HAUKOS, U.S. Geological Survey, Kansas Cooperative Fish and Wildlife Research Unit, 205 Leasure Hall, Manhattan, KS 660506, USA \\ VIRGINIA L. WINDER, Benedictine College, 1020 North 2nd Street, Westerman 200, Atchison, KS 66002, USA \\ CHRISTIAN A. HAGEN, Department of Fisheries and Wildlife, Oregon State University, 104 Nash Hall, Corvallis, OR 97331, USA \\ DANIEL S. SULLINS, Kansas State University, 212 Leasure Hall, Manhattan, KS 66506, USA \\ JAMES C. PITMAN, ${ }^{5}$ Kansas Department of Wildlife Parks and Tourism, 1830 Merchant, Emporia, KS 66801, USA \\ DAVID K. DAHLGREN, Education Specialist II, Department of Wildland Resources, Utah State University, Logan, UT 84322, USA
}

\begin{abstract}
The Southern Great Plains has been altered by conversion of native grassland to row-crop agriculture, which is considered the primary cause of declining lesser prairie-chicken (Tympanuchus pallidicinctus) populations. However, recent analyses indicate that direct loss of grassland has slowed while lesser prairie-chicken populations continue to decline, suggesting that remaining grasslands potentially suffer from degradation by various land uses (e.g., increased anthropogenic disturbance). Understanding the spatial ecology of lesser prairie-chickens relative to anthropogenic structures is important for conservation planning, habitat management, and infrastructure mitigation. We investigated effects of proximity to anthropogenic structures on home range and nest placement (second-order selection) and within home range space use (third-order selection) of radio-marked lesser prairiechickens $(n=285)$ at 2 scales of selection using resource utilization functions and resource selection functions. We collected data from birds marked in the Mixed-Grass Prairie and Short-Grass Prairie ecoregions of Kansas, USA, from 15 March 2013 to 14 March 2016. Home range placement did not vary by region or season, and lesser prairiechickens placed home ranges farther from powerlines and roads than would be expected at random. As distance increased from 0 to $3 \mathrm{~km}$ away from roads and powerlines, the relative probability of home range placement increased 1.66 and 1.54 times, respectively. Distance to powerline was the single most consistent variable negatively affecting nest placement. As the distance from powerline increased from 0 to $3 \mathrm{~km}$, the relative probability of nest placement increased 2.19 times. Distance to oil well did not influence placement of home ranges or nests. When pooled across regions, lesser prairie-chickens exhibited behavioral avoidance of powerlines, roads, and oil wells within their home range. Lesser prairie-chickens, on average, used space at greater intensities within their home range farther from wells, powerlines, and roads than available. Across breeding season phases, we found no evidence of increased behavioral avoidance of anthropogenic structures during the nesting or brooding phases compared to the lekking or post-breeding phases. Within home range space use during the brooding phase was not related to powerlines, wells, or roads. Our results indicate that avoidance of anthropogenic structures may result in functional habitat loss and continued fragmentation of remaining grassland habitat. Reduction or elimination of anthropogenic development in quality lesser prairie-chicken habitat and concentrating new development in already altered areas that are avoided by lesser prairie-chickens and no longer considered available habitat may reduce continued habitat degradation throughout the species' range and aid in population persistence. (c) 2018 The Wildlife Society.
\end{abstract}

KEY WORDS anthropogenic, Kansas, lesser prairie-chicken, management, mitigation, Tympanuchus pallidicinctus.

Received: 31 July 2018; Accepted: 7 July 2018

\footnotetext{
${ }^{1}$ E-mail: reid.plumb@wildlife.ca.gov

${ }^{2}$ Present Address: California Department of Fish and Wildlife, Montague, CA 96064, USA.

${ }^{3}$ Present Address: Ohio Department of Natural Resources, 2045 Morse Rd., Columbus, OH 43229, USA.

${ }^{4}$ Present Address: Department of Fish and Wildlife Conservation, Virginia Polytechnic Institute and State University, 134 Cheatham Hall, 310 W. Campus Dr., Blacksburg, VA 24060, USA.

${ }^{5}$ Present Address: Western Association of Fish and Wildlife Agencies, Emporia, KS 66801, USA.
}

Demand for domestic oil, natural gas, and wind energy within the United States has spurred increased anthropogenic disturbance in the Great Plains, which can negatively affect wildlife populations (Pruett et al. 2009a, Hagen et al. 2011, Allred et al. 2015). Development of energy infrastructure can result in direct habitat loss from the development footprint, behavioral responses to development-related activities, or fragmentation by way of infrastructure needed for exploration, development, or extraction (Northrup and Wittemyer 2013, Hovick et al. 
2014, Winder et al. 2014). Infrastructure development can cause direct mortalities from collisions with the structures themselves or vehicles, exacerbate fragmentation by providing access to further development, and provide travel corridors and perching sites for mammalian and avian predators (Wolfe et al. 2007, Naugle et al. 2011, Northrup and Wittemyer 2013, Allred et al. 2015).

The lesser prairie-chicken (Tympanuchus pallidicintus) is an endemic prairie grouse that resides in the southern Great Plains of Texas, New Mexico, Oklahoma, Kansas, and Colorado, USA, and has experienced significant declines in population size and occupied range during the last several decades (Hagen et al. 2013, Boal and Haukos 2016). Rangewide declines have been associated with the loss of habitat quantity and quality resulting from conversion of native prairie to cropland, energy development, invasive species, and unmanaged grazing (Hagen et al. 2004, Boal and Haukos 2016, Rodgers 2016, Van Pelt 2016). The lesser prairie-chicken has been petitioned for protection under the 1973 Endangered Species Act twice since 1995 but remains under review in response to a petition following a 2015 judicial ruling and subsequent removal of the species from the Federal List of Endangered and Threatened Wildlife in 2016. Despite the species' contentious legal status, threats to population persistence continue with increasing pressure from energy exploration and development, necessitating continued investigation of anthropogenic effects on lesser prairie-chicken populations.

In 2017, an estimated $88 \%$ of the remaining range-wide population of lesser prairie-chickens occurs in the Sand Sagebrush Prairie (SSPR), Short-Grass Prairie-Conservation Reserve Program Mosaic (SGPR), and Mixed-Grass Prairie (MGPR) ecoregions of Kansas (McDonald et al. 2014). Strategies for protection of the lesser prairie-chicken and its habitat are inherently complex because much of the species' range is rich with energy resources and widely used for fossil fuel exploration and extraction (Hagen and Giesen 2005, Bartuszevige and Daniels 2016, Van Pelt 2016). Research on multiple species of prairie grouse, including the lesser prairie-chicken, has demonstrated that these species are sensitive to anthropogenic disturbance on the landscape (e.g., Hagen 2010, Hovick et al. 2014). Most research investigating effects of anthropogenic disturbance on lesser prairie-chicken ecology has focused outside of their core area in the Sand Shinnery Oak Prairie (SOPR) ecoregion of Texas and New Mexico (Grisham et al. 2014, Godar 2016, Griffin 2016) and the southernmost portion of the MGPR ecoregion in Oklahoma (Pruett et al. 2009a,b; Dusang 2011). Contemporary research of anthropogenic disturbance on lesser prairie-chicken space use ecology is lacking in the core area of their range in Kansas. Only one study, occurring in the SSPR of southwest Kansas, has occurred in the lesser prairie-chicken's core area (Robel et al. 2004, Pitman et al. 2005, Hagen et al. 2011). Researchers have not investigated the effects of anthropogenic disturbance on lesser prairiechicken ecology in either the northern portion of the MGPR or the SGPR in south-central and northwest Kansas, respectively, or investigated if these effects vary regionally.
Additionally, researchers have examined the apparent avoidance of anthropogenic disturbance, but true avoidance, based on behavioral observations, has not been quantified for the genera, except in the congeneric populations of greater prairie-chickens (Tympanuchus cupido; Winder et al. 2014, Hovick et al. 2014, Bartuszevige and Daniels 2016).

Habitat, or "the resources and conditions present in an area that produce occupancy-including survival and reproduction-by a given organism" (Hall et al. 1997:175), varies in quality based on the accessibility of resources, whereby selection is an active process in which individuals can assess the quality of each habitat patch and are free to move to the highest quality patch (Haukos and Zavaleta 2016). Initial declines in lesser prairie-chicken populations were associated with direct habitat loss from conversion of native prairie to row-crop agriculture (Boal and Haukos 2016). However, for the last 2 decades, direct loss of grassland in the northern extent of the species range has been minimal (Ross et al. 2016, Spencer et al. 2017). Current lesser prairie-chicken populations have continued to decline despite grassland quantity remaining stable, suggesting that degradation of remaining grassland habitat may be the culprit. If increased anthropogenic development within the lesser prairie-chicken range results in behavioral displacement, avoidance, or a reduction in the probability of selection of otherwise quality habitat, especially for nesting and brooding, then the grassland habitat has either been degraded or functionally lost (Robel et al. 2004). Pitman et al. (2005), for example, estimated that in the SSPR of southwest Kansas anthropogenic features reduced their field site $53 \%$ from 13,380 ha of available habitat to 7,114 ha through avoidance behavior. Alternatively, if females select habitat near anthropogenic structures (e.g., oil wells), which results in failed nests, broods, or increased female mortality, then the habitat would become an ecological trap (Aldridge and Boyce 2007). Reduction in the availability or quality of grassland habitat could have severe negative effects on reproduction, recruitment, and population persistence, especially when coupled with an already fragmented landscape. Relating the impact of anthropogenic development on lesser prairie-chicken-habitat relationships is vitally important to understanding potential negative population consequences and directing appropriate mitigation strategies for industrial development.

We assessed lesser prairie-chicken space use and nest site selection to anthropogenic structures in the northern portion of the MGPR and the SGPR in Kansas at 2 scales of selection: second order (i.e., home range and nest placement) and third order (i.e., differential space use within a home range; Johnson 1980). Our specific objectives were to quantify effects of anthropogenic structures on lesser prairiechicken home range placement and space use between ecoregions for both 6-month seasons (i.e., breeding and nonbreeding), and within breeding season phases (i.e., lekking, nesting, brooding, post-breeding); investigate the influence of anthropogenic structures on nest-site selection; and provide distances that may buffer effects of these structures for use in development of future conservation and mitigation strategies. We predicted lesser prairie-chickens 


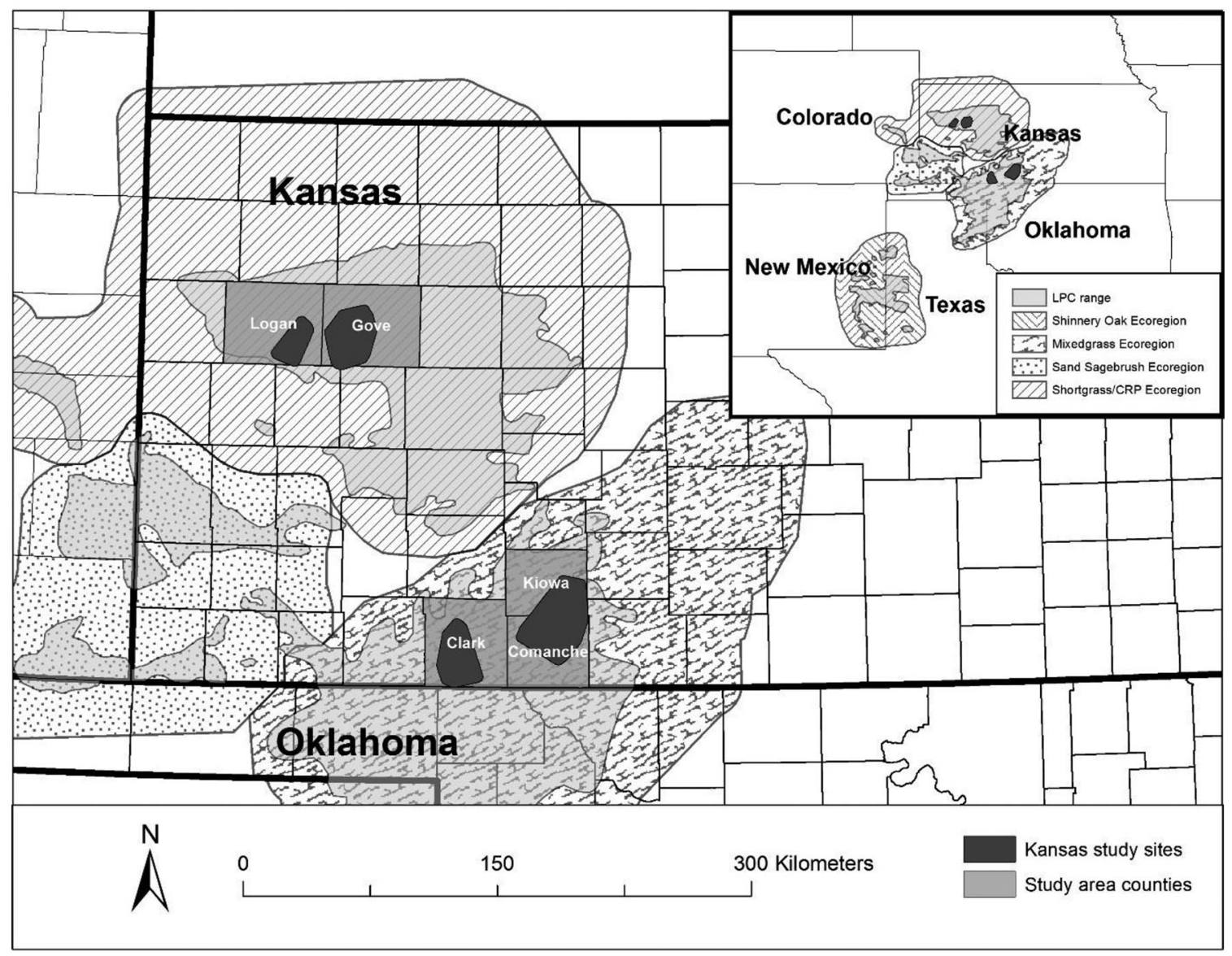

Figure 1. Study sites in northwest and south-central Kansas, USA, where we measured lesser prairie-chicken (LPC) space use, home range placement, and nest site selection in relation to anthropogenic structures, 2013-2016. Study areas in Kansas included northwest, with 2 sites (Logan in Logan County and Gove in Gove County), and south-central, with 2 sites (Red Hills in Kiowa and Comanche counties and Clark in Clark County).

would place home ranges, nests, and use space within their home range farther from structures than available; females would exhibit heightened avoidance of structures during the nesting and brooding phases of the breeding season; and lesser prairie-chicken home range placement and within home range space use would vary between ecoregions, with the magnitude of the effect of anthropogenic structures being greater in south-central Kansas (more intact landscape) than in northwest Kansas (fragmented landscape). Additionally, we predicted that the influence of anthropogenic structures would not differ between the 26 -month breeding and nonbreeding season because anthropogenic structures do not change between seasons.

\section{STUDY AREA}

Our research was conducted from 15 March 2013 to 14 March 2015 in the SGPR (i.e., northwest Kansas) and MGPR and SSPR ecoregions (i.e., south-central Kansas) of Kansas, which supported approximately $88 \%$ of the rangewide lesser prairie-chicken population in 2017 (McDonald et al. 2017). We collected data during 26 -month biological seasons, the breeding season (15 Mar-15 Sep) and nonbreeding season (16 Sep-14 Mar; Winder et al. 2017, Robinson et al. 2017). We established study area boundaries by creating minimum convex polygons around all very high frequency (VHF) and satellite platform transmitting terminal (SAT-PTT) locations generated from marked birds in each area, excluding dispersal events (unidirectional movements $>5 \mathrm{~km}$ ), using the minimum bounding geometry tool in ArcGIS 10.2 (Environmental Systems Research Group [ESRI], Redlands, CA, USA; Robinson et al. 2017). Each study area was comprised of 2 field sites in each ecoregion. The northwest Kansas study area was $1,714 \mathrm{~km}^{2}$ and encompassed sites located in Gove and Logan counties (Fig. 1). Research in the Gove County site was conducted solely on private lands. Research in Logan County was centered on The Smoky Valley Ranch owned and managed by The Nature Conservancy and surrounding private lands.

The northwest study area was a mosaic of short-grass and mixed-grass prairies, land enrolled in the Conservation Reserve Program (CRP) with the United States Department of Agriculture, and row-crop agriculture on silt-loam soils (McDonald et al. 2014). Long-term average temperatures in the study area ranged between $-8.5^{\circ} \mathrm{C}$ and $33.1^{\circ} \mathrm{C}$ (High Plains Regional Climate Center [HPRCC] 2017). Elevation ranged from $733 \mathrm{~m}$ to $961 \mathrm{~m}$ (U.S. Geological Survey [USGS] 2015). Long-term average annual precipitation in the northwest study area ranged from $46.7 \mathrm{~cm}$ to $56.6 \mathrm{~cm}$ and 
the average frost-free period ranged from 132 days to 168 days (Kansas State University [KSU] 2018, HPRCC 2018). During the study period, annual precipitation was $56.6 \mathrm{~cm}, 65.3 \mathrm{~cm}$, and $53.6 \mathrm{~cm}$ for 2013, 2014, and 2015, respectively. Annual temperatures ranged from minimums of $-20.0^{\circ} \mathrm{C},-23.9^{\circ} \mathrm{C}$, and $-20.6^{\circ} \mathrm{C}$ to maximums of $41.7^{\circ} \mathrm{C}$, $38.3^{\circ} \mathrm{C}$, and $38.9^{\circ} \mathrm{C}$ in 2013,2014 , and 2015 , respectively (HPRCC 2018). Dominant vegetation in the region included blue grama (Bouteloua gracilis), hairy grama ( $B$. hirsuta), buffalograss (B. dactyloides), little bluestem (Schizachyrium scoparium), sideoats grama (B. curtipendula), big bluestem (Andropogon gerardii), Illinois bundleflower (Desmanthus illinoensis), prairie sunflower (Helianthus petiolaris), annual buckwheat (Eriogonum annum), sand milkweed (Asclepias arenaria), nine-anther dalea (Dalea enneandra), and western ragweed (Ambrosia psilostachya; Lauver et al. 1999). Some of the grass species originally planted within the CRP fields included little bluestem, sideoats grama, big bluestem, switchgrass (Panicum virgatum), blue grama, buffalograss, and Indian grass (Sorghastrum nutans; Fields et al. 2006). After original planting in the mid-late 1980s, some CRP fields were interseeded with forbs in the mid-1990s including white sweet clover (Melilotus alba), yellow sweet clover (M. officinalis), Maximillian sunflower (Helianthus maximiliani), Illinois bundleflower, purple prairie clover (Dalea purpurea), and prairie coneflower (Ratibida columnifera; Fields et al. 2006). Wheat, sorghum, and corn were the major crops in the region. Dominant fauna in northwest Kansas consisted of coyote (Canis latrans), swift fox (Vulpes velox), striped skunk (Mephitis mephitis), northern harrier (Circus cyaneus), Swainson's hawk (Buteo swainsoni), red-tailed hawk (Buteo jamaicensis), ring-necked pheasant (Phasianus colchicus), white-tailed deer (Odocoileus virginianus), and mule deer (Odocoileus hemionus; Robinson et al. 2017). The dominant land uses in this region were rotational and season-long livestock grazing, row-crop agriculture, CRP, oil extraction, electrical distribution, and rural towns.

The northwest Kansas landscape was comprised of 54.0\%, $36.0 \%$, and $7.4 \%$ grassland, crop, and CRP, respectively (Robinson et al. 2018). The northwest Kansas site was characterized as a fragmented grassland landscape (Robinson et al. 2018). The density of anthropogenic structures in northwest Kansas was 0.34 oil wells $/ \mathrm{km}^{2}, 0.31 \mathrm{~km}$ of powerline $/ \mathrm{km}^{2}$, and $0.43 \mathrm{~km}$ of road $/ \mathrm{km}^{2}$, respectively.

The south-central Kansas study area was $1,203 \mathrm{~km}^{2}$ and encompassed sites located on private lands in Kiowa, Comanche, and Clark counties (Fig. 1). This area consisted of mixed-grass prairie on loamy soils, with primary land uses of livestock grazing, oil and gas extraction, and limited rowcrop agriculture in bottomland areas. Long-term average temperatures ranged from $-7.5^{\circ} \mathrm{C}$ to $33.8^{\circ} \mathrm{C}$ (HPRCC 2017). Elevation ranged from $515 \mathrm{~m}$ to $703 \mathrm{~m}$ (USGS 2015). Long-term average annual precipitation in the south-central study area ranged from $56.6 \mathrm{~cm}$ to $72.5 \mathrm{~cm}$ and the average frost-free period ranged from 144 days to 225 days (KSU 2018, HPRCC 2018). During the study period, annual precipitation was $72.4 \mathrm{~cm}, 63.2 \mathrm{~cm}$, and $70.6 \mathrm{~cm}$ for 2013 ,
2014, and 2015, respectively. Annual temperatures ranged from minimums of $-18.9^{\circ} \mathrm{C},-22.2^{\circ} \mathrm{C}$, and $-14.4^{\circ} \mathrm{C}$ to maximums of $42.2^{\circ} \mathrm{C}, 38.9^{\circ} \mathrm{C}$, and $41.7^{\circ} \mathrm{C}$ in 2013,2014 , and 2015, respectively (HPRCC 2018). Dominant vegetation within the region included little bluestem, blue grama, hairy grama, sideoats grama, buffalograss, sand dropseed (Sporobolus cryptandrus), alkali sacaton (S. airoides), Louisiana sagewort (Artemisia ludiviciana), annual sunflower (Helianthus annuus), western ragweed, sand sagebrush, Russian thistle (Salsola kali), kochia (Kochia scoparium), and eastern redcedar (Juniperus virginiana; Lauver et al. 1999). Dominant fauna in south-central Kansas consisted of coyote, striped skunk, American badger (Taxidea taxus), northern harrier, red-tailed hawk, ring-necked pheasant, and white-tailed deer (Robinson et al. 2017).

The south-central Kansas landscape was comprised of $86.7 \%, 8.9 \%$, and $2.2 \%$ grassland, crop, and CRP, respectively. The south-central region of Kansas was characterized by large intact tracts of native mixed-grass prairie with minimal row-crop agriculture and was less fragmented than northwest Kansas (Robinson et al. 2018). The density of anthropogenic features in south-central Kansas was $0.21 \mathrm{wells} / \mathrm{km}^{2}, 0.29 \mathrm{~km}$ of powerline $/ \mathrm{km}^{2}$, and $0.39 \mathrm{~km}$ of $\mathrm{road} / \mathrm{km}^{2}$, respectively.

\section{METHODS}

\section{Radio-Telemetry}

We captured lesser prairie-chickens on leks sites during spring (Mar-May) and fall (Sep-Oct) of 2013-2015 using walk-in drift traps, rope-triggered drop-nets, and magnetic drop-nets (Haukos et al. 1990, Silvy et al. 1990, Schroeder and Braun 1991). We identified sex using the presence of air-sacs, greater pinnae length in males, and tail feather color (females have barred tail feathers and males have mainly black tail feathers; Copelin 1963).

We marked female lesser prairie-chickens with either a 15-g bib-style VHF transmitter (A3960, Advanced Telemetry System, Isanti, MN, USA) or a rump-mounted 22-g SAT-PTT global positioning system (GPS) transmitter (Solar Argos-GPS PTT 100, Microwave Telemetry, Columbia, MD, USA; Bedrosian and Craighead 2007, Wegge et al. 2007). We opportunistically equipped male lesser prairie-chickens with the remaining SAT-PTT transmitters after females stopped attending leks in May. We used male prairie-chicken data in nonbreeding season analyses because home range size and space use behavior did not differ between sexes (Robinson et al. 2018). We released captured individuals within 20 minutes of initial capture at the capture site. All capture and handling procedures were approved by the Kansas State University Institutional Animal Care and Use Committee (protocols 3241 and 3703) and Kansas Department of Wildlife, Parks, and Tourism scientific collection permit (SC-042-2013, SC-079-2014, SC-001-2015, SC-014-2016).

We located lesser prairie-chickens equipped with VHF transmitters 3-5 times/week and collected spatial locations via triangulation (Cochran and Lord 1963). We triangulated 
individuals from 3-5 locations using a 3-element hand-held Yagi antenna and either an Advanced Telemetry Systems Receiver (R4000, R4500) or a Communications Systems 49 Receiver (R1000, Communications Specialists, Orange, CA, USA). We took bearings of locations $\geq 15$ degrees apart and within 20 minutes to decrease error from bird movement. We used Location of a Signal (LOAS; Ecological Software Solutions LLC, Hegymagas, Hungary) to estimate the Universal Transverse Mercator (UTM) location and error polygon around the location of the individual. If individuals could no longer be located because of dispersal from the study area, we used a fixed-wing Cessna aircraft (Cessna, Wichita, KS) to locate the lost individual. Birds outfitted with a SATPTT transmitter recorded up to 10 GPS positions a day with 18-m accuracy between 0600 and 2200. We downloaded points weekly from the Argos satellite system (CLS America, Largo, MD, USA) to obtain UTM locations, locate nests, and find mortalities. We tracked marked lesser prairiechickens from date of capture until they emigrated from the study area and we could no longer locate the lost individual, the radio failed, or the animal died.

\section{Breeding Season Phases}

Lesser prairie-chicken space use varies depending on the behavioral phase and season (Riley et al. 1994, Jamison 2000, Plumb 2015, Robinson 2015). Therefore, the probability of interaction with and the magnitude of influence from anthropogenic development on lesser prairie-chicken space use likely varies and should be investigated separately for each phase and season. During the breeding season, we categorized behavioral phases for each female using empirical data of reproductive status (e.g., lekking, nesting, brood rearing, post-breeding) to generate biologically relevant estimates of space use rather than using subjective calendar dates.

We defined lekking, the time when females were visiting leks, as the time from capture or start of the breeding season (15 Mar) to the start of nest initiation and the time between a failed nest and nest initiation of a renest attempt. We pooled the nesting phase across all nest attempts and began at the start of nest initiation until we determined the fate of the nest. At this juncture, females could enter the brooding phase if the nest was successful, enter back into the lekking phase for another breeding attempt, or omit from further breeding attempts and enter the post-breeding phase. Females that had successful nests entered the brooding phase until we determined the fate of the brood using brood flushes. If a brood failed between brood flushes, we used the median date as the transition from the brooding phase into the post-breeding phase. We determined the end of the breeding season as the average date of brood break up (15 Sep). Females could end the breeding season in either the brooding phase if the brood was still with the female until the average brood break up date, or in the post-breeding phase if all other breeding attempts failed.

\section{Spatial Analysis}

Space use.-We collected spatial locations using VHF and SAT-PTT transmitters at 2 different temporal resolutions: 3-5 locations/week for VHF and approximately 70 locations/week for SAT-PTT transmitters. Differences in data resolutions required us to use separate methods of space use estimation. We used a fixed-kernel density estimator within the function kernelUD in the program adehabitatHR (Calenge 2006) of the statistical program $\mathrm{R}$ ( $\mathrm{R}$ Core Development Team, Vienna, Austria) to estimate space use for coarse temporal spatial data generated from VHFmarked individuals. We used the dpik function in the program KernSmooth (KernSmooth version 2.23-15, https://cran.r-project.org/package=KernSmooth, accessed 29 June 2015) to select a direct plug-in bandwidth for smoothing of the kernel estimation (Wand and Jones 1995). We created utilization distributions (UD) for all marked individuals that had $\geq 25$ locations each for both breeding and nonbreeding seasons (Pruett et al. 2009b). We did not estimate VHF UDs for specific breeding season phases because there were not enough locations collected within each phase to meet the minimum location requirement.

We estimated space use of SAT-PTT-marked individuals using the Brownian bridge movement model (BBMM; Horne et al. 2007) with the BBMM function in the BBMM package (Nielson et al. 2012) of the statistical program $R$. The BBMM is a continuous-time stochastic model of movement in which the probability of being in a specific space at a given time is conditioned on starting and ending locations, time elapsed between those 2 locations, error associated with the transmitter, and mobility of the organism (Horne et al. 2007). This methodology explicitly makes use of auto-correlated telemetry data and is well suited for GPS data (Bullard 1991, Walter et al. 2011). We limited the sample to only females that had $>90$ locations ( $\sim 10$ days). We removed from the dataset birds that did not meet the location requirement. We did not use segments of the animal track that had starting and ending locations with elapsed time between them $>2,880$ minutes ( $>2$ days) in the Brownian motion variance calculation. We estimated the biotelemetry error as 1 standard deviation from the average linear error calculated from a beacon test (5.7 m; Nielson et al. 2012).

For both methods of estimation, we used only female locations to estimate space use during the breeding season. Females influence population demography because they take sole parental care of the young and they were our focus during the breeding season (Hagen et al. 2008). To investigate nest site selection and female space use separately, we removed all repeat nest locations from female space use data during the breeding season so we would not bias the UD (Hagen et al. 2011). We conducted a separate analysis investigating the relationship between nest placement and anthropogenic structures.

Space use centroids. - We defined space use centroids as the geographic center of the $1 \%$ isopleth polygon of the BBMM and kernel UDs. We choose the $1 \%$ percent isopleth polygon because it represents the area of greatest concentration of use within the UD (Winder et al. 2015). We generated isopleth polygons for each estimated BBMM and kernel UD by importing each bird's UD into the Geospatial Modeling Environment (Beyer 2012) and using the isopleth tool. We then imported isopleth polygons into ArcGIS 10.2 and used 
the feature-to-point tool to estimate the center of gravity or centroid of each $1 \%$ percent isopleth polygon created. If multiple centroids were created for an individual UD because of large-scale movements, dispersal, or different areas selected within the home range as a result of behavioral state, we defined each centroid as an independent location of home range placement through time and used all created centroids for analysis.

Space use predictors. - We hypothesized that 3 different anthropogenic structures reported to negatively influence lesser prairie-chicken home range placement and nest site selection in other regions would influence lesser prairiechicken selection in our study areas: distance to oil and gas wells (hereafter wells), distance to distribution powerlines (hereafter powerlines), and distance to roads (county gravel and paved; Pitman et al. 2005, Pruett et al. 2009b, Hagen et al. 2011). We did not include ranch roads (i.e., unimproved 2-tracks) because these have relatively low frequency of vehicle traffic. Additionally, we did not differentiate between gravel and paved roads or distribution and transmission lines because paved roads and transmission lines occurred in low frequency within our study sites and were not often encountered by marked lesser prairiechickens. We were unable to determine the power source of all active wells on the landscape and therefore, did not distinguish among power sources operating wells. We included all roads (paved or gravel) and well pumping units (electric or gas powered) in the analysis as either well or road (Hagen et al. 2011). We collected active well and road layers from the Kansas GIS and Data and Support Center (www. kansasgis.org, accessed 9 Sep 2015). We obtained powerline layers from the Kansas Corporation Commission (http:// www.kcc.state.ks.us/, accessed 16 Sep 2014).

Anthropogenic structures are likely spatially correlated because development of a region would require a clustering of basic infrastructure (e.g., roads and powerlines), especially for oil and gas exploration and extraction. Variables exhibiting multicollinearity can be problematic for coefficients in regression modeling (Belsley et al. 1980). We tested for multicollinearity among variables using condition indices and variance decomposition rates, as described by Belsley et al. (1980), where condition indices $\geq 30$ coupled with $\geq 2$ variables with variance decomposition proportions $>50 \%$ indicate collinearity issues. If variables were indicated as being highly correlated, we chose the variable we felt had the greatest biological meaning according to the current knowledge of anthropogenic avoidance in published literature (Doherty et al. 2008). Further, when variables were moderately correlated, we checked for stability and consistency of regression coefficient estimates as we added predictor variables to models. If a regression coefficient switched signs when correlated variables were in the same model, we removed one variable from the analysis if the other was an important predictor (Doherty et al. 2008).

We were also interested in investigating regional and season variation in the effects of our anthropogenic predictors. We included 2 categorical variables for region and season and an interaction term to determine if the effect of the anthropogenic variables changed as a function of either region (northwest or south-central), season (breeding or nonbreeding), or both.

\section{Statistical Analysis}

Second-order selection. -We used a resource selection framework (i.e., used [1] vs. available [0] study design) to test the effects of distance to anthropogenic structures on lesser prairie-chicken home range and nest placement on the landscape (Boyce et al. 2002, Manly et al. 2002). We considered the area within a $3-\mathrm{km}$ buffer of home range centroids and nests as the maximum perceived area available in which a lesser prairie-chicken could place their home range or nest. We selected $3 \mathrm{~km}$ as the area available for home range and nest placement because the average distance of non-dispersing lesser prairie-chickens who traveled from initial marking to the last location generated within either the 6-month breeding or nonbreeding season was $2.78 \mathrm{~km}(95 \% \mathrm{CI}=2.13,3.42)$. Additionally, the average distance from lek of capture to nest location was 3.35 km (95\% CI =3.12, 3.58; R. T. Plumb, Kansas State University, unpublished data). To reduce the effect of landcover type on selection and isolate the effects of anthropogenic structures, we generated cover type polygons within all 3-km buffered areas for grassland and crop using the Playa Lakes Joint Venture landcover classification layer (McLachlan 2012). We then randomly distributed 3 times the number of home range centroids in direct proportion to the number of centroids witnessed in grassland ( $93 \%)$ and crop $(\sim 7 \%)$ cover types to generate an estimate of distances to anthropogenic structures that would be available at random (Northrup and Wittemyer 2013). Unlike home range centroids, all nests were located within grassland cover types. Therefore, we randomly distributed 3 times the number of nest site locations only in grassland patches found in the $3-\mathrm{km}$ buffered areas. We did not evaluate the influence of other landscape characteristics (e.g., landscape composition, terrain ruggedness, microhabitat) because we were interested in exploring only the spatial response of lesser prairie-chickens to anthropogenic structures. In doing so, we acknowledge that this approach is assuming that our disturbance metrics were not confounded by other latent sources of landscape heterogeneity. However, by using general landcover categories (i.e., grassland, crop) to constrain our placement of available locations, in relation to witnessed locations, we accounted for coarser resolution habitat selection, which allowed us to explicitly isolate effects of anthropogenic structures.

As a result of using 3 times the number of available locations compared to observed locations, our models were potentially biased toward the larger sample of available locations. We used an importance weight, which gives full weight to used locations but a fractional weight proportional to the ratio of observed locations to available locations (0.33) to reduced potential bias with our larger available sample. Weighting effectively adjusts the standard errors of the estimates and allows for traditional inferences of standard errors and $P$ values for coefficient estimates (Aldridge and Boyce 2007, Carpenter et al. 2010). 
For home range placement analysis, we assigned variables into 1 of 2 model categories: distance to anthropogenic structures and regional or seasonal effects. We then created models for each possible combination within each category and ranked models using Akaike's Information Criterion corrected for small samples sizes $\left(\mathrm{AIC}_{i}\right.$; Burnham and Anderson 2002). We carried over models that were equally parsimonious $\left(\leq 2 \Delta \mathrm{AIC}_{c}\right)$ within each category to the next hierarchy of model selection and allowed models to compete across categories to test if the additional information increased model fit (Doherty et al. 2008). For nests, we created a set of models with each possible combination of anthropogenic variables and a categorical variable for region and ranked models using $\mathrm{AIC}_{c}$ (Burnham and Anderson 2002). We selected the model with the lowest $\mathrm{AIC}_{c}$ value and greatest model weight $\left(w_{i}\right)$. We considered models with $\Delta \mathrm{AIC}_{c} \leq 2$ to be equally parsimonious. For both analyses, if beta $(\beta)$ coefficient estimates from the top model differed from zero ( $95 \% \mathrm{CI}$ did not overlap 0 ), then we considered the variable to be influential. We estimated the relative probability of home range and nest placement in relation to the distance from each influential variable $(0-3 \mathrm{~km})$ using the predict function and plotted the relative probability of use curve while holding all other variables at their mean. We conducted all resource selection functions in Program R.

Third-order selection.-We measured differential space use relative to anthropogenic structures within the home range of each female marked with a SAT-PTT during the 6-month breeding season and both males and females during the 6month nonbreeding season. During the breeding season, we also estimated differential space use for each of the breeding season phases. We did not use male prairie-chicken data during the breeding season because of differential space use behavior between sexes during the breeding season. We combined male and female UDs because space use behavior is similar between sexes during the nonbreeding season (Robinson et al. 2017). We did not use UDs estimated from VHF data in the third-order analysis because the BBMM estimation creates a more representative estimate of individual space use when compared to the kernel method (Horne et al. 2007). If we monitored individual lesser prairie-chickens in multiple seasons or years, we considered each 6-month breeding or nonbreeding season and breeding season phase to be independent for use of our complete data set (Winder et al. 2014). We used UDs to represent space use as a continuous, probabilistic variable. We estimated the Brownian motion variance $\left(\widehat{\sigma}_{\mathrm{m}}^{2}\right)$, which is related to the animal's mobility, separately for each individual.

The spatial extent of space use and availability of variables of interest were defined by the $99 \%$ isopleth of the BBMM UD boundary for each lesser prairie-chicken's home range (Kertson and Marzluff 2011, Winder et al. 2014). We created a raster surface with $30-\mathrm{m}^{2}$ cells within the UD, where we assigned use values, bounded from 1 to 99 , to each cell based on the relative volume (height) of the UD for that cell. We then $\log _{\mathrm{e}}$ transformed space use data to meet assumptions of multiple linear regression models (Kertson and Marzluff 2011). We used resource utilization functions (Marzluff et al. 2004) in the RUF.fit package (Handcock 2007) for Program $R$ to relate the effect that distance to well, road, and powerline have on lesser prairie-chicken within home range space use. Resource utilization functions are based on relative space use, where the unit of study is the individual utilization distribution. A resource utilization function relates the intensity of use to the resources available within the $99 \%$ isopleth on a cell-by-cell basis in a multiple linear regression framework to obtain $\beta$ coefficients. These coefficients indicate the relative importance or influence of each variable to the variation in the utilization distribution of each lesser prairie-chicken (Marzluff et al. 2004, Kertson and Marzluff 2011). We developed population inferences by calculating a mean standardized $\beta$ coefficient $(\bar{\beta})$ for each predictor and pooled across years for each 6-month seasonal period and breeding season phase (Winder et al. 2014). We investigated regional effects by pooling across seasons for each region specifically. If the standardized coefficients differed from zero based on the range of their $95 \%$ confidence intervals, we inferred that the influence of that variable was either greater $(+)$ or less (-) than expected compared to the availability of that resource within the home range (Marzluff et al. 2004, Winder et al. 2014).

Distance to anthropogenic structures.-We quantified distances of all estimated home range centroids to anthropogenic structures using the near tool in ArcMap 10.2. The near tool measures the shortest linear distance between locations and anthropogenic structures. Hagen et al. (2011) indicated that distance metrics that are averaged across all individuals may give spurious results because anthropogenic structures are not ubiquitously distributed across the landscape and, therefore, the distances may not produce a true representation of avoidance. To characterize distances for potential use in conservation planning and compare to Hagen et al. (2011), we used the lower tenth percentile of the distribution of observed distances because this represents the portion of the study population that occurred closest to the anthropogenic structures. Furthermore, the lower tenth percentile is not too extreme to be subject to excessive random variation in its estimation. We report all means with their associated 95\% confidence intervals unless otherwise noted.

\section{RESULTS}

We captured 273 female and 341 male lesser prairie-chickens in northwest and south-central Kansas during spring 2013, 2014, and 2015. We deployed 170 SAT-PTT transmitters $($ female $=150$, male $=20)$ and $115 \mathrm{VHF}$ transmitters (all female) on captured lesser prairie-chickens. Of the 150 females marked with SAT-PTT transmitters, we successfully created 147 home range UDs during the 6-month breeding season and 87 UDs during the 6-month nonbreeding season. Within the 6-month breeding season, we created 138 UDs during the lekking phase, 124 UDs during the nesting (initial nests and re-nests) phase, 25 UDs during the brooding 
phase, and 65 UDs during the post-breeding phase. Using UDs generated from VHF- and SAT-PTT-marked birds, we estimated 764 home range centroids, 322 for northwest Kansas and 442 for south-central Kansas. Pooled across regions, we generated 359 home range centroids during the breeding season and 405 during the nonbreeding season. We located 235 lesser prairie-chicken nests across all study sites (northwest $n=99$, south-central $n=136)$.

We calculated large variance decomposition proportions between our distance to road (87\%) and distance to powerline (35\%) variables as expected. However, the condition index for these variables (4.0) did not meet the suggested threshold $(\geq 30)$ to suggest collinearity problems (Belsley et al. 1980). Therefore, for home range placement analysis, we retained all hypothesized variables in both modeling frameworks. However, for nest placement analysis, the addition of or removal of other variables switched the coefficient sign of distance to road, indicating its instability. Therefore, we removed the distance to road metric from the nest placement analysis.

\section{Second-Order Selection}

Home range placement.-Model evaluation of anthropogenic metrics indicated that distance to powerlines and distance to roads were the most influential predictors of home range placement and these variables composed the only parsimonious model $\left(\Delta \mathrm{AIC}_{\mathrm{c}} \leq 2.0\right)$ with the greatest support $\left(w_{i}=0.74 ;\right.$ Table 1$)$. The top ranked model for regional and seasonal effects was the null model (Table 1). Univariate models for region and season were also parsimonious $\left(\Delta \mathrm{AIC}_{c} \leq 2.0\right)$; however, because the null model was the top-ranked model and held the greatest model weight

Table 1. Rankings of models testing the influence of distance to anthropogenic structures and categorical variables of region (northwest and south-central) and season (breeding and nonbreeding) on lesser prairiechicken home range placement in Kansas, USA, 2013-2016.

\begin{tabular}{lrrrr}
\hline \multicolumn{1}{c}{ Model } & $\boldsymbol{\Delta A I C}_{\boldsymbol{c}}{ }^{\mathbf{a}}$ & $\boldsymbol{K}^{\mathbf{b}}$ & $\boldsymbol{w}_{\boldsymbol{i}}^{\mathbf{c}}$ & $\mathbf{D e v}^{\mathbf{d}}$ \\
\hline Linear metrics & & & & \\
$\quad$ Powerline+road & 0.00 & 3 & 0.74 & $1,970.10$ \\
Powerline+well+road & 2.20 & 4 & 0.25 & $1,969.95$ \\
$\quad$ Powerline & 10.00 & 2 & 0.01 & $1,995.59$ \\
$\quad$ Powerline+well & 10.90 & 3 & 0.00 & $1,993.25$ \\
Road & 19.60 & 2 & 0.00 & $2,004.26$ \\
Road+well & 21.60 & 3 & 0.00 & $2,004.26$ \\
Well & 74.40 & 2 & 0.00 & $2,112.18$ \\
$\quad$ Null & 75.60 & 1 & 0.00 & $2,118.26$ \\
Categorical variables & & & & \\
$\quad$ Null & 0.00 & 1 & 0.51 & $2,118.26$ \\
$\quad$ Region & 2.00 & 2 & 0.19 & $2,118.26$ \\
Season & 2.00 & 2 & 0.19 & $2,118.26$ \\
$\quad$ Region+season & 4.00 & 3 & 0.07 & $2,118.26$ \\
$\quad$ Region $\times$ season & 6.00 & 4 & 0.03 & $2,118.26$ \\
Region+season+region $\times$ season & 6.00 & 4 & 0.03 & $2,118.26$ \\
\hline
\end{tabular}

a Difference in Akaike's Information Criterion, corrected for a small sample size.

b Number of parameters.

${ }^{c}$ Model weight.

${ }^{\mathrm{d}}$ Deviance. $\left(w_{i}=0.51\right)$, we did not include regional or seasonal effects in our final model.

Lesser prairie-chickens placed home ranges farther from roads $(\beta=0.00028,95 \% \mathrm{CI}=0.00017,0.00039)$ and powerlines $(\beta=0.00031,95 \% \mathrm{CI}=0.00021,0.00042)$ than would be expected at random. As distance increased from 0 to $3 \mathrm{~km}$ away from roads, the relative probability of home range placement increased 1.54 times (Fig. 2). Similarly, as the distance from powerline increased from 0 to $3 \mathrm{~km}$, the relative probability of home range placement increased 1.66 times (Fig. 2). Distance to well was not indicated as an important predictor of home range placement.

Nest placement.-There was no single top ranked model in the model set (Table 2). We made inference based on the top 4 models, all of which were parsimonious $\left(\Delta \mathrm{AIC}_{\mathrm{c}} \leq 2.0\right)$ and had a combined model weight of 0.99 . Distance to powerline was the single most consistent variable and was in all of the top models. Distance to well and region were not informative predictors of lesser prairie-chicken nest placement $(\beta=$ $-0.00008,95 \% \mathrm{CI}=-0.00027,0.00012 ; \beta=-0.37,95 \%$
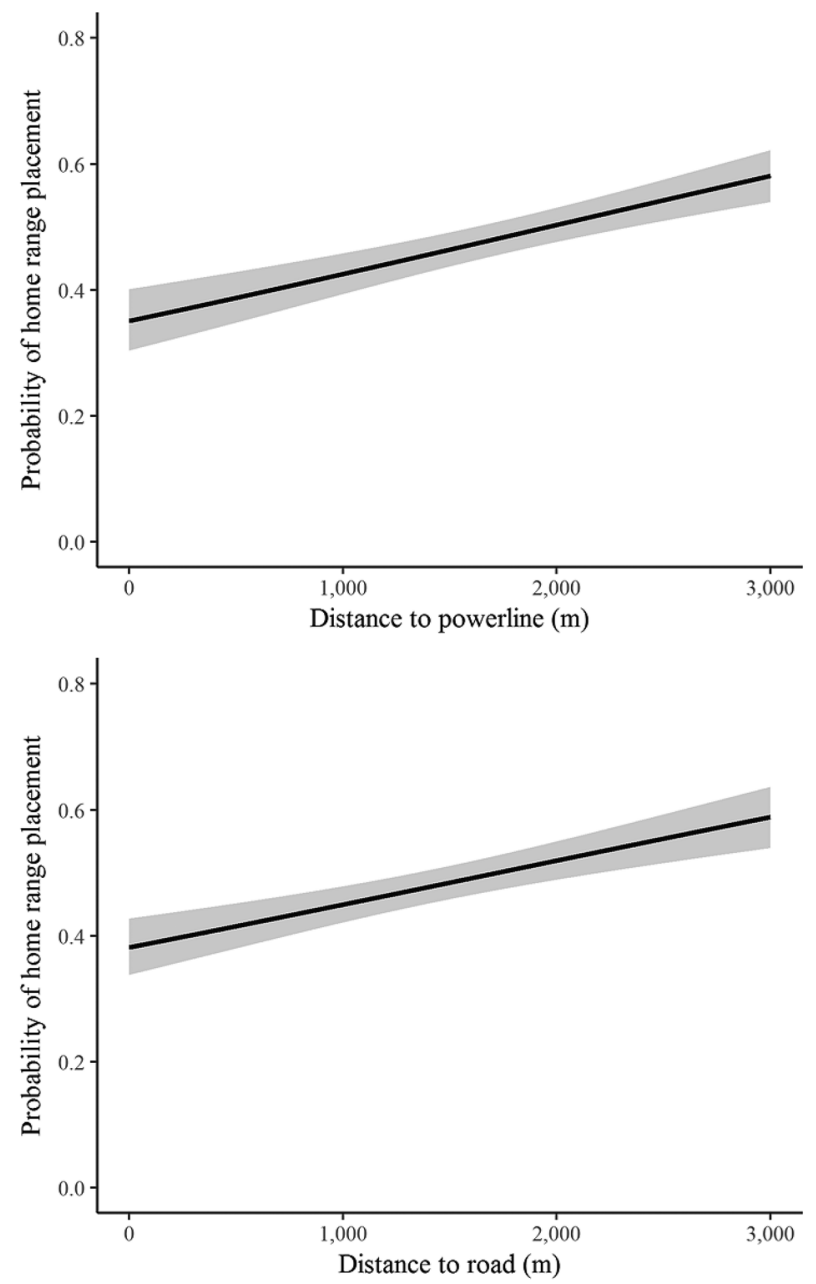

Figure 2. Relative probability of use curves depicting lesser prairie-chicken home range placement $( \pm 95 \% \mathrm{CI})$ in relation to the nearest powerline and road in Kansas, USA, 2013-2016. 
Table 2. Rankings of models testing the influence of distance to anthropogenic structures and categorical variables of region (northwest and south-central) and season (breeding and nonbreeding) on lesser prairiechicken nest site selection in Kansas, USA, 2013-2016.

\begin{tabular}{lrrrr}
\hline Model & $\boldsymbol{\Delta} \mathbf{A I C}_{\boldsymbol{c}}^{\mathbf{a}}$ & $\boldsymbol{K}^{\mathbf{b}}$ & $\boldsymbol{w}_{\boldsymbol{i}}^{\mathbf{c}}$ & $\mathbf{D e v}^{\mathbf{d}}$ \\
\hline Powerline & 0.00 & 2 & 0.34 & 603.06 \\
Powerline+region & 0.10 & 3 & 0.32 & 600.20 \\
Powerline+well+region & 1.30 & 4 & 0.18 & 599.50 \\
Powerline+well & 1.60 & 3 & 0.15 & 602.70 \\
Well & 22.90 & 2 & 0.00 & 640.09 \\
Region & 23.10 & 2 & 0.00 & 640.47 \\
Well+region & 24.90 & 3 & 0.00 & 640.09 \\
Null & 740.00 & 1 & 0.00 & $1,039.20$ \\
\hline
\end{tabular}

a Difference in Akaike's Information Criterion, corrected for a small sample size.

${ }^{\mathrm{b}}$ Number of parameters.

c Model weight.

d Deviance.

$\mathrm{CI}=-0.78,0.035)$. Distance to powerline was the only significant predictor of lesser prairie-chicken nest placement with females placing nests farther from powerlines than expected at random $(\beta=0.00046,95 \% \mathrm{CI}=0.00031$, $0.00062)$. As the distance from powerline increased from 0 to $3 \mathrm{~km}$, the relative probability of nest placement increased 2.19 times (Fig. 3).

Third-order selection.-For data pooled across both regions and seasons, all anthropogenic predictors were significant (Fig. 4A). Lesser prairie-chickens, on average, used space at greater intensities within their home range farther from wells $(\bar{\beta}=0.08,95 \% \mathrm{CI}=0.05,0.17)$, powerlines $(\bar{\beta}=0.10,95 \%$ $\mathrm{CI}=0.04,0.16)$, and roads $(\bar{\beta}=0.11,95 \% \mathrm{CI}=0.05,0.17)$.

Within home range space use varied regionally. In northwest Kansas, individuals exhibited behavioral avoidance of powerlines $(\bar{\beta}=0.18,95 \% \mathrm{CI}=0.10,0.25$; Fig. $4 \mathrm{~B})$, whereas in south-central Kansas individuals avoided oil and gas wells $(\bar{\beta}=0.12,95 \% \mathrm{CI}=0.06,0.17$; Fig. $4 \mathrm{C})$. Roads were avoided in both regions (northwest $\bar{\beta}=0.11,95 \%$

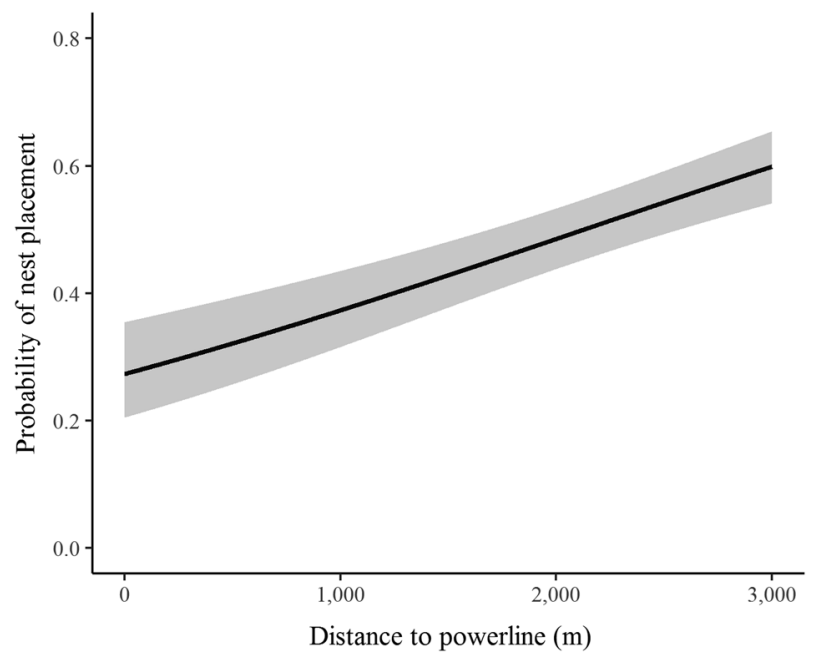

Figure 3. Relative probability of use curve depicting lesser prairie-chicken nest placement $( \pm 95 \% \mathrm{CI})$ in relation to nearest powerline in Kansas, USA, 2013-2016.
$\mathrm{CI}=0.04,0.19$; south-central $\bar{\beta}=0.11,95 \% \mathrm{CI}=0.02$, 0.20; Fig. 4B, C). Lesser prairie-chickens used space farther from wells during the breeding $(\bar{\beta}=0.06,95 \% \mathrm{CI}=0.01$, 0.12 ; Fig. $4 \mathrm{D})$ and nonbreeding seasons $(\bar{\beta}=0.10,95 \%$ $\mathrm{CI}=0.02,0.19$; Fig. 4E). Lesser prairie-chickens used space at greater intensities farther from powerlines $(\bar{\beta}=0.14,95 \%$ $\mathrm{CI}=0.07,0.22$; Fig. 4D) than was available within their home ranges during the breeding season but did not avoid powerlines during the nonbreeding season. Inversely, roads were not avoided during the breeding season but were avoided during the nonbreeding season $(\bar{\beta}=0.21,95 \%$ $\mathrm{CI}=0.09,0.32$; Fig. 4E).

We did not observe increases in avoidance behavior during the nesting or brooding phases of the breeding season for either northwest or south-central Kansas. Females in northwest Kansas used space within their home range farther from powerlines and roads during the lekking $(\bar{\beta}=0.17,95 \% \mathrm{CI}=0.08,0.26 ; \bar{\beta}=0.11,95 \% \mathrm{CI}=0.02$, $0.19)$ and nesting phases $(\bar{\beta}=0.26,95 \% \mathrm{CI}=0.12,0.39$; $\bar{\beta}=0.27,95 \% \mathrm{CI}=0.14,0.40)$ and only powerlines during the post-breeding phase $(\bar{\beta}=0.08,95 \% \mathrm{CI}=0.01,0.16$; Fig. 5). Distance to well was not a significant predictor for any of the breeding season phases in northwest Kansas. In contrast, distance to well was the only significant predictor for females in south-central Kansas. Females in south-central Kansas avoided wells during the lekking phase only $(\bar{\beta}=0.11,95 \% \mathrm{CI}=0.02,0.19$; Fig. 5$)$. No other predictors affected space use in the other breeding season phases for lesser prairie-chickens in south-central Kansas. Space use during the brooding phase was not related to any hypothesized predictors for either region, implying that the lack of predictive ability is a result of prairie-chickens using space in equal proportion to the resource availability within their home range (Fig. 5).

\section{Distances}

Though not all linear distance predictors affected female home range placement or within home range space use, the lowest tenth percentile of home range centroids, as described by Hagen et al. (2011), did suggest that lesser prairiechicken's space use occurs at greater distances away from roads $(355 \mathrm{~m})$ and powerlines $(587 \mathrm{~m})$ than would be expected at random (183 m, $216 \mathrm{~m}$; Table 3). Differences between the tenth percentile distances of observed $(467 \mathrm{~m})$ and available locations $(428 \mathrm{~m})$ for wells was negligible. Additionally, regional differences in the tenth percentile distances were negligible (Table 3).

\section{DISCUSSION}

Our study adds to the growing consensus that increased anthropogenic disturbance and development in grasslands negatively affects lesser prairie-chicken space use and results in behavioral displacement. We found that lesser prairiechickens consistently avoided powerlines across all analyses, avoidance of structures was exhibited across 2 scales of selection, and within home range avoidance responses were not elevated during the nesting and brooding phases of the reproductive season compared to other phases. Although 
direct loss of grassland in the northern extent of the lesser prairie-chicken range has been minimal during the last 2 decades, current populations have declined (Ross et al. 2016, Spencer et al. 2017). Our results, combined with others (Robel et al. 2004, Pitman et al. 2005, Pruett et al. 2009a,b, Hagen et al. 2011, Hovick et al. 2014, Winder et al. 2015), indicate that anthropogenic development, at a minimum, degrades lesser prairie-chicken habitat and may result in functional elimination of available habitat. Anthropogenic development within remaining grassland patches further exacerbates effects of previous habitat loss and fragmentation, which may be a proximate reason for continued declines.

Powerlines are one of the few structures that have been a consistent negative factor on the landscape for lesser prairiechickens and other species of prairie-grouse (Pitman et al.

A

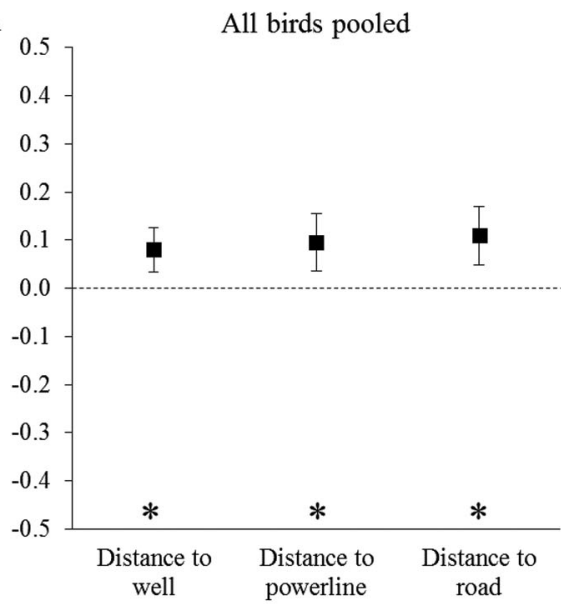

B

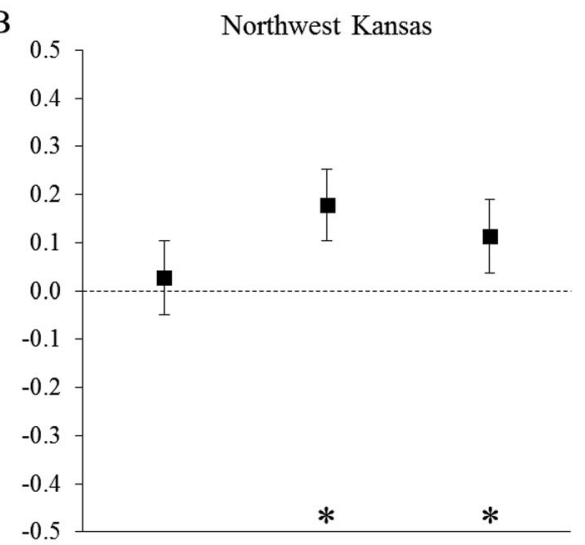

$\mathrm{C}$

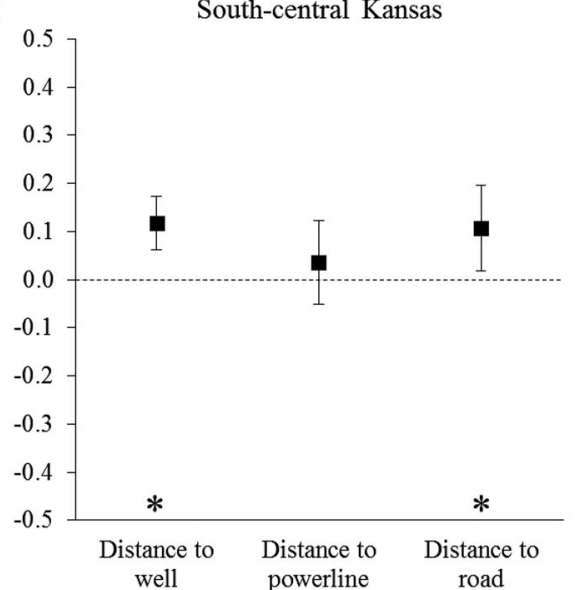

$\mathrm{D}$

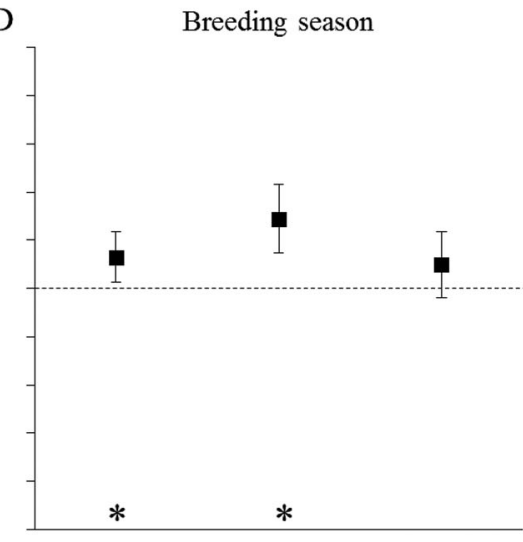

$\mathrm{E}$

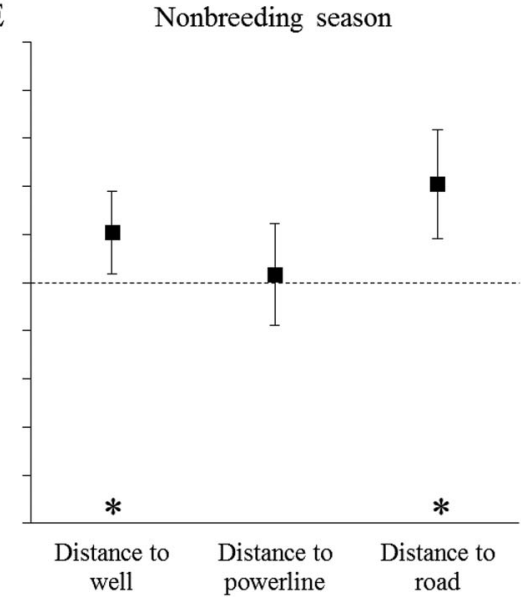

Figure 4. Mean standardized $\beta$ coefficients $( \pm 95 \% \mathrm{CI}$ ) of lesser prairie-chicken resource utilization functions for all data pooled across region and season in Kansas, USA (A), for northwest (B) and south-central Kansas (C) pooled across season, and for the breeding (15 Mar-15 Sep; C) and nonbreeding (16 Sep$14 \mathrm{Mar}$; ) seasons pooled across region. Estimates represent all birds marked within each region and season regardless of fate. Asterisks denote a significant response at the population level ( $\pm 95 \% \mathrm{CI}$ of $\bar{\beta}$ s that do not overlap zero). A significant positive $\bar{\beta}$ coefficient signifies behavioral avoidance and a significant negative $\bar{\beta}$ coefficient signifies behavioral attraction. 


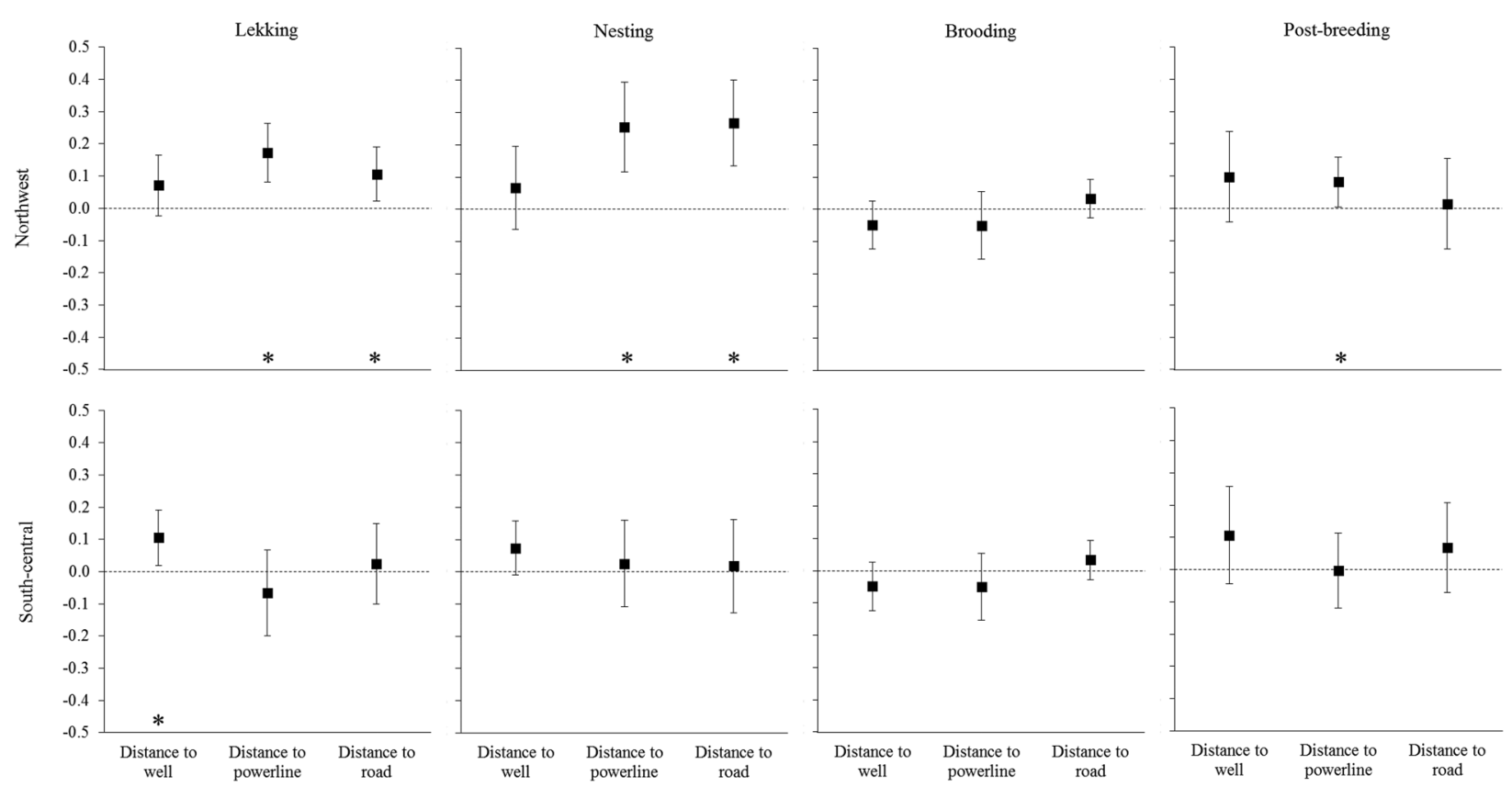

Figure 5. Mean standardized $\beta$ coefficients $( \pm 95 \% \mathrm{CI})$ for female lesser prairie-chicken resource utilization functions within each region (northwest and south-central Kansas, USA, 2013-2016). Estimates are for each biological phase defined for the breeding season. Asterisks denote a significant response at the population level ( $\pm 95 \%$ CI of $\bar{\beta}$ s that do not overlap zero). A significant positive $\bar{\beta}$ coefficient signifies behavioral avoidance and a significant negative $\bar{\beta}$ coefficient signifies behavioral attraction.

2005, Pruett et al. 2009b, Hagen et al. 2011, Grisham et al. 2014, Hovick et al. 2014). Powerlines have been implicated as obstructions to prairie grouse movement, nest site selection, and general habitat use (Pitman et al. 2005, Pruett et al. 2009b, Hagen et al. 2011, Grisham et al. 2014). Our results corroborate previous investigations; lesser prairie-chickens placed home ranges and nests farther from powerlines than would be expected at random and exhibited behavioral avoidance within their home ranges. Further, minimum avoidance distance of powerlines $(587 \mathrm{~m})$ was reasonably similar to those observed by other studies on lesser prairie-chickens (Pruett et al. 2009b, Hagen et al. 2011).

We posit that avoidance of powerlines may have been a product of 3 different mechanisms: increased predation attempts or perceived predation presence from raptors, a general neophobic response to tall structures, or ultraviolet discharges from the powerline. In prairie landscapes, perch and wait raptors such as red-tailed hawks, Swainson's hawks, rough-legged hawks (B. lagopus), ferruginous hawks ( $B$. regalis), great horned owls (Bubo virginianus), and golden eagles (Aquila chysaetos) use powerlines and other standing structures for perching to scan for potential prey (Behney et al. 2011, Boal 2016). These larger and less agile raptors lack the flight skills necessary to successfully take lesser prairie-chickens in the air. Their presence has been documented as inciting a flushing response from prairiechickens but with little to no known success (Behney et al. 2011). Continued predation attempts from raptors using powerline structures may explain why lesser prairie-chickens place home ranges and use space within their home range farther from powerlines than would be expected at random.

Table 3. Summary statistics representing the mean $(\bar{x})$, lower and upper $95 \%$ confidence intervals (L95\%, U95\%), and the maximum distance of the nearest tenth percentile (10th \%) of linear distances $(\mathrm{m})$ between each anthropogenic structure and all observed and available home range centroids pooled across regions $(n=764)$, in northwest (NW) Kansas, USA, $(n=322)$, and south-central (SC) Kansas $(n=442)$, USA, 2013-2016. Sample sizes for random locations were 3 times the number of observed locations.

\begin{tabular}{|c|c|c|c|c|c|c|c|c|c|c|c|c|}
\hline \multirow[b]{2}{*}{ Feature type } & \multicolumn{4}{|c|}{ Pooled } & \multicolumn{4}{|c|}{ NW Kansas } & \multicolumn{4}{|c|}{ SC Kansas } \\
\hline & $\bar{x}$ & L95\% & U95\% & 10th \% & $\bar{x}$ & L95\% & U95\% & 10th \% & $\bar{x}$ & L95\% & U95\% & 10th \% \\
\hline \multicolumn{13}{|l|}{ Observed } \\
\hline Well & 1,826 & 1,743 & 1,908 & 467 & 1,987 & 1,834 & 2,140 & 437 & 1,708 & 1,621 & 1,795 & 501 \\
\hline Powerline & 2,218 & 2,131 & 2,304 & 587 & 1,879 & 1,768 & 1,989 & 591 & 2,465 & 2,344 & 2,585 & 584 \\
\hline Road & 1,925 & 1,832 & 2,017 & 355 & 1,622 & 1,501 & 1,743 & 317 & 2,145 & 2,016 & 2,275 & 391 \\
\hline \multicolumn{13}{|l|}{ Available } \\
\hline Well & 1,678 & 1,629 & 1,726 & 428 & 1,879 & 1,796 & 1,963 & 445 & 1,531 & 1,474 & 1,587 & 421 \\
\hline Powerline & 1,512 & 1,462 & 1,562 & 216 & 1,344 & 1,274 & 1,414 & 208 & 1,634 & 1,565 & 1,703 & 237 \\
\hline Road & 1,252 & 1,206 & 1,297 & 183 & 1,000 & 951 & 1,049 & 169 & 1,434 & 1,365 & 1,504 & 212 \\
\hline
\end{tabular}


A female lesser prairie-chicken that is tending a nest may be a more susceptible target than a female that can move freely at will and is not tied to a reproductive input (Hagen and Giesen 2005, Behney et al. 2011). Adult female mortality tends to peak during the nesting period (Patten et al. 2005, Hagen et al. 2007, Wolfe et al. 2007, Plumb 2015). The majority of breeding season losses are due to predation, with roughly equal proportions attributed to mammals and raptors (Haukos and Broda 1989, Holt 2012). Cause-specific mortality results from this study indicated that the majority of predation-related mortalities came from avian predators and coincided with raptor migration peaks (46\%; Plumb 2015). Increased susceptibility while nesting may explain why our results indicated an elevated negative response toward powerlines with the relative probability of nest placement increasing as the distance from nearest powerline increased.

Lesser prairie-chicken avoidance of powerlines may be a result of neophobia, or an extreme fear or dislike for something new (Walters et al. 2014). Lesser prairie-chickens evolved in prairie landscapes that were mostly devoid of tall natural structures such as trees, as a consequence of limited rainfall and fire. However, as fire was removed from the landscape, trees have begun to encroach into the grassland ecosystem. Lesser prairie-chickens avoid trees such as eastern redcedar (Juniperus virginiana) and honey mesquite (Prosopis glandulos) across their range (Boggie et al. 2017, Lautenbach et al. 2017). Our results, and others, provided clear evidence that lesser prairie-chickens avoided tall anthropogenic structures such as powerlines, poles, and frame towers (Pitman et al. 2005, Hagen et al. 2011, Hovick et al. 2014, Grisham et al. 2014).

Finally, avoidance of habitat near powerlines is a perplexing behavior because the lines and pylons are neither an impenetrable physical barrier nor always associated with human traffic (Pruett et al. 2009b, Tyler et al. 2014). Integrating information on visual function with the characteristics of powerline function provides evidence that avoidance may be linked with the ability of lesser prairie-chickens to detect ultraviolet light (UV; Tyler et al. 2014). Ultraviolet discharges occur as standing corona along cables and irregular flashes on insulators, with the discharge spectrum (200-400 nm) below the lower limit of human vision but within the visible range of birds, rodents, and reindeer or caribou (Rangifer tarandus; Maruvada 2000, Tyler et al. 2014). The ability for birds to see UV light emanating from powerlines may explain the lesser prairieschickens avoidance rather than from physical or neophobic pressures. Further, during dark periods of the day, retinal sensitivity from lesser prairie-chickens could increase the effects of UV light associated with powerlines because, in darkness, lesser prairie-chickens may see powerlines not as dim, passive structures but, rather, as lines of flickering light stretching across the landscape (Tyler et al. 2014). This does not explain avoidance during daylight periods or when lines are not transmitting electricity but could be a classic example of conditioning where the events are perceived as threatening (Tyler et al. 2014). Unfortunately, potential avoidance mechanisms are confounded with one another and are difficult to tease apart. Regardless, the negative response seen at the second- and third-order selection scales indicate that powerlines reduce the available habitat perceived by lesser prairie-chickens. Continued functional fragmentation of remaining habitat patches from powerlines in already fragmented landscapes may compound negative effects on lesser prairie-chicken movement, habitat availability and quality, and population connectivity.

Lesser prairie-chicken movements and home ranges frequently intersect roads, suggesting that roads are more permeable to lesser prairie-chickens than tall linear structures such as powerlines (Pruett et al. 2009b, Hagen et al. 2011). However, noise and disturbance associated with roads reduce habitat use and nest site selection of prairie grouse species (Lyon and Anderson 2003, Pitman et al. 2005, Hagen et al. 2011, Blickley et al. 2012). Our results indicate that lesser prairie-chickens place home ranges farther from roads than would be expected at random. Additionally, lesser prairiechickens also exhibited behavioral avoidance of roads within their home range, supporting the hypothesis that disturbance associated with roads functionally eliminates otherwise available habitat. A novel finding from our study was the instability of distance to road as a predictor for nest-site placement. Previous research indicates nesting female lesser prairie-chickens place nest sites farther from paved roads than would be expected at random, even when vegetation characteristics are similar near these edges (Pitman et al. 2005, Hagen et al. 2011). Paved roads were rare in both study areas; only $23 \mathrm{~km}$ of 2-lane paved roads were within the $1,249-\mathrm{km}^{2}$ area we considered available for nesting. The limited exposure to paved roads may explain why distance to road was not a stable predictor.

The southern Great Plains is increasingly relied upon to produce energy for the country (Bartuszevige and Daniels 2016). Increased demand for domestic energy resources and advancements in mineral extraction has spurred an expansion in oil and gas development throughout the range of the lesser prairie-chicken. Presence of oil and gas wells has been documented as displacing multiple species of grouse through structure avoidance (Hovick et al. 2014). Results from our analysis indicated that the effect from wells varied among scales of selection. At the second-order selection scale, distance to well was not a significant predictor of home range or nest placement. However, lesser prairie-chickens did behaviorally avoid wells by disproportionately selecting areas farther from wells than available within their home range.

Well density (number of wells/unit area) has successfully been use to characterize the negative effects of energy development on habitat use of mule deer (Odocoileus hemionus), greater sage grouse (Centrocercus urophasianus), and lesser prairie-chickens (Sawyer et al. 2006, Walker et al. 2007, Doherty et al. 2008, Hagen et al. 2011). For example, the likelihood that greater sage grouse would use otherwise available winter range was diminished by $10 \%$ with the development of 1 well $/ 4 \mathrm{~km}^{2}$ (Doherty et al. 2008). We predict that well density would be a superior metric to use in future studies when compared to that of distance to well and 
that lesser prairie-chickens will place home ranges and nests in areas with lower well density than available. Further, research investigating well density should also investigate the effect of well distribution and clustering to aid conservation decisions on mitigating the effects of oil and gas development.

Contrary to our prediction, we did not record heightened within home range avoidance of anthropogenic structures during critical nesting and brood-rearing phases. However, at the home range and nest site selection scale, lesser prairiechickens exhibited heightened sensitivity when placing nests compared to home range centroids; females were more than twice as likely to place a nest $3 \mathrm{~km}$ from a powerline than $0 \mathrm{~km}$, whereas the probability of home range placement increased by only $65 \%$ over the same distance. There was no measurable within home range avoidance of anthropogenic structures during the brooding phase, which was inconsistent with other breeding season phases.

Increased development of anthropogenic structures on the landscape, especially in grassland cover types, could have profound effects on population viability. Functional habitat loss, especially for nesting, from increased development could prove detrimental to demographic rates (Holloran 2005, Doherty et al. 2008). If females choose to use habitat with increased structure densities for reproduction, such decisions may lead to nest, brood, or female mortality greater than natural variability and the grassland habitat would become an ecological trap (Aldridge and Boyce 2007). Furthermore, if displacement or a resulting ecological trap affects productivity of the area, persistence of leks and the occupancy of these patches may diminish over time and lead to decreases in local populations (Hagen et al. 2011).

Reduction in habitat quality has been implicated as a contemporary mechanism for continued decreases in lek attendance, persistence, and associated population declines (Haukos and Zavaleta 2016, Rodgers 2016). Our results combined with others (Robel et al. 2004, Pitman et al. 2005, Hagen et al. 2011, Grisham et al. 2014) demonstrate the negative effects of anthropogenic development on home range placement, nest site selection, and space use by lesser prairie-chickens. Increasing evidence clearly supports the contention that disturbance and encroachment from anthropogenic structures continually degrade remaining habitat fragments that support lesser prairie-chicken populations.

\section{MANAGEMENT IMPLICATIONS}

Increasing buffer distances for distribution lines, secondary roads, and oil and gas pads to $>550 \mathrm{~m},>350 \mathrm{~m}$, and $>450 \mathrm{~m}$, respectively, would maximize effectiveness of mitigation measures by management agencies. Grassland habitats within approximately $3 \mathrm{~km}$ of home range centroids and nest sites would benefit from protection from any initial or further anthropogenic disturbances. Removing or burying powerlines and decommissioning roads that penetrate or border remaining grassland patches, will likely reduce lesser prairie-chicken avoidance and increase habitat at multiple scales. Decommissioning and reclaiming retired well structures and pads may mitigate lesser prairie-chicken avoidance, with the priority for well sites in intact grasslands. If constructing anthropogenic structures in lesser prairiechicken habitat is necessary, efforts to reduce avoidance and increase home range and nest placement may include clustering structures together on the periphery of habitat patches or near already compromised areas such as heavily trafficked or paved roads, current standing structures, or agricultural fields.

\section{ACKNOWLEDGMENTS}

Any use of trade, firm, or product names is for descriptive purposes only and does not imply endorsement by the United States Government. We thank K. E. Sexson, J. L. Kramer, M. W. Mitchener, J. A. Prendergast, P. G. Kramos, A. A. Flanders, J. Reitz, B. S. T. Hyberg, J. D. Kraft, and J. D. Lautenbach for their assistance with the project. We appreciate all of the assistance from M. Bain, the Smoky Valley Ranch of The Nature Conservancy, private landowners for allowing us access to their land to conduct this research, and all of the technicians who assisted with this research. Funding for the project was provided by Kansas Wildlife, Parks, and Tourism (Federal Assistance Grant KS W-73-R-3); United States Department of Agriculture Farm Services CRP Monitoring, Assessment, and Evaluation (12-IA-MRE CRP TA number 7, KSCFWRU RWO 62); and Natural Resources Conservation Service, Lesser Prairie-Chicken Initiative.

\section{LITERATURE CITED}

Aldridge, C. L., and M. S. Boyce. 2007. Linking occurrence and fitness to persistence: habitat-based approach for endangered greater sage-grouse. Ecological Applications 17:508-526.

Allred, B. W., W. K. Smith, D. Twidwell, J. H. Haggerty, S. W. Running, D. E. Naugle, and S. D. Fuhlendorf. 2015. Ecosystem services lost to oil and gas in North America: net primary production reduced in crop and rangelands. Science 348:401-402.

Bartuszevige, A. M., and A. Daniels. 2016. Impacts of energy development, anthropogenic structures, and land use change on lesser prairie-chickens. Pages 205-220 in D. A. Haukos and C. W. Boal, editors. Ecology and conservation of lesser prairie-chickens. Studies in Avian Biology. CRC Press, Boca Raton, Florida, USA.

Bedrosian, B., and D. Craighead. 2007. Evaluation of techniques for attaching transmitters to common raven nestlings. Northwestern Naturalist 88:1-6.

Behney, A. C., C. W. Boal, H. A. Whitlaw, and D. R. Lucia. 2011. Interactions of raptor and lesser prairie-chicken at leks in the Texas Southern High Plains. Wilson Journal of Ornithology 123:332-338.

Belsley, D. A., E. Kuh, and R. E. Welsch. 1980. Regression diagnostics: identifying influential data and sources of collinearity. John Wiley and Sons, New York, New York, USA.

Beyer, H. L. 2012. Geospatial Modelling Environment (version 0.7.2.0). http://www.spatialecology.com/gme. Accessed 07 Jan 2013.

Blickley, J. L., D. Blackwood, and G. L. Patricelli. 2012. Experimental evidence for the effects of chronic noise on the abundance of greater sagegrouse at leks. Conservation Biology 26:461-471.

Boal, C. W. 2016. Predation and lesser prairie-chickens. Pages 145-158 in D. A. Haukos and C. W. Boal, editors. Ecology and conservation of lesser prairie-chickens. Studies in Avian Biology. CRC Press, Boca Raton, Florida, USA.

Boal, C. W., and D. A. Haukos. 2016. The lesser prairie-chicken: a brief introduction to the grouse of the southern Great Plains. Pages 1-14 in D. A. Haukos and C. W. Boal, editors. Ecology and conservation of lesser prairie-chickens. Studies in Avian Biology. CRC Press, Boca Raton, Florida, USA. 
Boggie, M. A., C. R. Strong, D. Lusk, S. C. Carleton, W. R. Gould, R. L. Howard, C. Nichols, M. Falkowski, and C. A. Hagen. 2017. Impacts of mesquite distribution on seasonal space use of lesser prairie-chickens. Rangeland Ecology \& Management 70:68-77.

Boyce, M. S., P. R. Vernier, S. E. Nielsen, and F. K. Schmiegelow. 2002. Evaluating resource selection functions. Ecological Modelling 157:281-300.

Bullard, F. 1991. Estimating the home range of an animal: a Brownian Bridge approach. Thesis, University of North Carolina, Chapel Hill, USA.

Burnham, K. P., and D. R. Anderson. 2002. Model selection and multimodel inference: a practical information-theoretic approach. Springer, New York, New York, USA.

Calenge, C. 2006. The package adehabitat for the R software: a tool for the analysis of space and habitat use by animals. Ecological Modelling 197:516-519.

Carpenter, J., C. L. Aldridge, and M. S. Boyce. 2010. Sage-grouse habitat selection during the winter in Alberta. Journal of Wildlife Management 74:1806-1814.

Cochran, W. W., and R. D. Lord Jr. 1963. A radio-tracking system for wild animals. Journal of Wildlife Management 27:9-24

Copelin, F. F. 1963. The lesser prairie chicken in Oklahoma. Technical Bulletin No. 6. Oklahoma Department of Wildlife Conservation, Oklahoma City, USA.

Doherty, K. E., D. E. Naugle, B. L. Walker, and J. M. Graham. 2008. Greater sage-grouse winter habitat selection and energy development. Journal of Wildlife Management 72:187-195.

Dusang, D. 2011. Impacts of energy development on lesser prairie-chicken ecology and management. Thesis, University of Oklahoma, Norman, USA.

Fields, T. L., G. C. White, W. C. Gilgert, and R. D. Rodgers. 2006. Nest and brood survival of lesser prairie-chickens in west central Kansas. Journal of Wildlife Management 70:931-938.

Godar, A. 2016. Influence of climate change and land use on lesser prairiechicken (Tympanuchus pallidicinctus) population persistence in the sand sagebrush and short-grass prairie. Thesis, Texas Tech University, Lubbock, USA.

Griffin, C. 2016. The influence of environmental and landscape variables on lesser prairie-chickens in the sand shinnery oak prairie ecoregion of Texas and New Mexico and the mixed-grass prairie ecoregion of Oklahoma and Kansas. Thesis, Texas Tech University, Lubbock, USA.

Grisham, B. A., P. K. Bordsdorf, C. W. Boal, and K. K. Boydston. 2014. Nesting ecology and nest survival of lesser prairie-chickens on the southern High Plains of Texas. Journal of Wildlife Management 78:857-866.

Hagen, C. A. 2010. Impacts of energy development on prairie grouse ecology: a research synthesis. Transactions of the North American Wildlife and Natural Resources Conference 75:96-103.

Hagen, C. A., and K. M. Giesen. 2005. Lesser prairie-chicken (Tympanuchus pallidic in ctus). Account 364 in A. Poole, editor. The birds of North America. Cornell Lab of Ornithology, Ithaca, New York, USA.

Hagen, C. A., B. A. Grisham, C. W. Boal, and D. A. Haukos. 2013. A meta-analysis of lesser prairie-chicken nesting and brood-rearing habitats: implications for habitat management. Wildlife Society Bulletin 37:750-758.

Hagen, C. A., B. E. Jamison, K. M. Giesen, and T. Z. Riley. 2004. Guidelines for managing lesser prairie-chicken populations and their habitats. Wildlife Society Bulletin 32:69-82.

Hagen, C. A., J. C. Pitman, T. M. Loughin, B. K. Sandercock, R. Robel, and R. D. Applegate. 2011. Impacts of anthropogenic features on habitat use by lesser prairie-chickens. Pages 63-76 in B. K. Sandercock, K. Martin, and G. Segelbacher, editors. Ecology, conservation, and management of grouse: Published for the Cooper Ornithological Society. University of California Press, Berkeley, USA.

Hagen, C. A., J. C. Pitman, B. K. Sandercock, R. J. Robel, and R. D. Applegate. 2007. Age-specific survival and probable causes of mortality in female lesser prairie-chickens. Journal of Wildlife Management 71:518-525.

Hagen, C. A., B. K. Sandercock, J. C. Pitman, R. J. Robel, and R. D. Applegate. 2008. Spatial variation in lesser prairie-chicken demography: a sensitivity analysis of population dynamics and management alternatives. Journal of Wildlife Management 73:1325-1332.

Hall, L. S., P. R. Krausman, and M. L. Morrison. 1997. The habitat concept and a plea for standard terminology. Wildlife Society Bulletin 25:171-182.
Handcock, M. S. 2007. Estimates of the resource utilization function. http:// CRAN.R-project.org/package=RUF. Accessed 25 Dec 2014.

Haukos, D. A., and G. S. Broda. 1989. Northern harrier (Cercus cyaneus) predation of lesser prairie-chicken (Tympanuchus pallidicinctus). Journal of Raptor Research 23:182-183.

Haukos, D. A., L. M. Smith, and G. S. Broda. 1990. Spring trapping of lesser prairie-chickens. Journal of Field Ornithology 61:20-25.

Haukos, D. A., and J. C. Zavaleta. 2016. Habitat. Pages 99-132 in D. A. Haukos and C. W. Boal, editors. Ecology and conservation of lesser prairie-chickens. Studies in Avian Biology. CRC Press, Boca Raton, Florida, USA.

High Plains Regional Climate Center [HPRCC]. 2017. County level data. https://hrpcc.unl.edu/datasets.php?set=CountyData. Accessed 1 sep 2017.

High Plains Regional Climate Center [HPRCC]. 2018. High Plains RCC CLIMOD. https://climod.unl.edu/. Accessed 22 Jun 2018.

Holloran, M. J. 2005. Greater sage-grouse (Centrocercus urophasianus) population response to natural gas field development in western Wyoming. Dissertation, University of Wyoming, Laramie, USA.

Holt, R. D. 2012. Breeding season demographics of a lesser prairie-chicken (Tympanucbus pallidicinctus) population in the northeast of the Texas panhandle. Dissertation, Texas Tech University, Lubbock, USA.

Horne, J. S., E. O. Garton, S. M. Krone, and J. S. Lewis. 2007. Analyzing animal movements using Brownian Bridges. Ecology 88:2354-2363.

Hovick, T. J., R. D. Elmore, D. K. Dahlgren, S. D. Fuhlendorf, and D. M. Engle. 2014. Evidence of negative effects of anthropogenic structures on wildlife: a review of grouse survival and behavior. Journal of Applied Ecology 51:1680-1689.

Jamison, B. E. 2000. Lesser prairie-chicken chick survival, adult survival, and habitat selection and movements of males in fragmented rangelands of southwestern Kansas. Thesis, Kansas State University, Manhattan, USA.

Johnson, D. H. 1980. The comparison and usage and availability measurements for evaluating resource preference. Ecology 61:65-71.

Kansas State University [KSU]. 2018. Normal annual precipitation map. http://climate.k-state.edu/basics/. Accessed 22 Jun 2018.

Kertson, B. N., and J. M. Marzluff. 2011. Improving studies of resource selection by understanding resource use. Environmental Conservation 38:18-27.

Lautenbach, J. M., R. T. Plumb, S. G. Robinson, C. A. Hagen, D. A. Haukos, and J. C. Pitman. 2017. Lesser prairie-chicken avoidance of trees in a grassland landscape. Rangeland Ecology \& Management 70:78-86.

Lauver, C. L., K. Kindscher, F. L. Don, and R. Schneider. 1999. A classification of the natural vegetation of Kansas. Southwestern Naturalist 44:421-443.

Lyon, A. G., and S. H. Anderson. 2003. Potential gas development impacts on sage grouse nest initiation and movement. Wildlife Society Bulletin 31:486-491.

Manly, B. F. J., L. L. McDonald, D. L. Thomas, T. L. McDonald, and W. P. Erickson. 2002. Resources selection by animals: statistical design and analysis for field studies. Second edition. Kluwer Academic Publishers, Boston, Massachusetts, USA.

Maruvada, P. S. 2000. Corona performance of high voltage transmission lines. Research Studies Press, Baldock, Herfordshire, United Kingdom.

Marzluff, J. M., J. J. Millspaugh, P. Hurvitz, and M. S. Handcock. 2004. Relating resources to a probabilistic measure of space use: forest fragments and Stellar's jays. Ecology 85:1411-1427.

McDonald, L., G. Beauprez, G. Gardner, J. Griswold, C. Hagen, F. Hornsby, D. Klute, S. Kyle, J. Pitman, and T. Rintz. 2014. Range-wide population size of the lesser prairie-chicken: 2012 and 2013. Wildlife Society Bulletin 38:536-546.

McDonald, L., K. Nasman, T. Rintz, F. Hornsby, and G. Gardner. 2017. Range-wide population size of the lesser prairie-chicken: 2012 to 2017. Western EcoSystems Technology, Inc. (WEST), Laramie, Wyoming, USA.

McLachlan, M. 2012. Playa Lakes Joint Venture landcover accuracy assessment report. Playa Lakes Joint Venture, Lafayette, Colorado, USA.

Naugle, D. E., K. E. Doherty, B. L. Walker, M. J. Holloran, and H. E. Copeland. 2011. Energy development and greater sage-grouse. Studies in Avian Biology 38:489-504.

Nielson, R. M., H. Sawyer, and T. L. McDonald. 2012. BBMM: Brownian Bridge movement model. http://CRAN.R-project.org/package=BBMM. Accessed 20 Jul 2014. 
Northrup, J. M., and G. Wittemyer. 2013. Characterizing the impacts of emerging energy development on wildlife, with an eye towards mitigation. Ecology Letters 16:112-125.

Patten, M. A., D. H. Wolfe, E. A. Shochat, and S. K. Sherrod. 2005. Effects of microhabitat and microclimate selection on adult survivorship of the lesser prairie-chicken. Journal of Wildlife Management 69:1270-1278.

Pitman, J. C., C. A. Hagen, R. J. Robel, T. M. Loughin, and R. D. Applegate. 2005. Location and success of lesser prairie-chicken nests in relation to vegetation and human disturbance. Journal of Wildlife Management 69:1259-1269.

Plumb, R. T. 2015. Lesser prairie-chicken movement, space use, survival, and response to anthropogenic structures in Kansas and Colorado. Thesis, Kansas State University, Manhattan, USA.

Pruett, C. L., M. A. Patten, and D. H. Wolfe. 2009a. It's not easy being green: wind energy and a declining grassland bird. BioScience 59:257-262.

Pruett, C. L., M. A. Patten, and D. H. Wolfe. 2009b. Avoidance behavior by prairie grouse: implications for development of wind energy. Conservation Biology 23:1253-1259.

Riley, T. Z., C. A. Davis, M. A. Candelaria, and H. R. Suminski. 1994. Lesser prairie-chicken movements and home ranges in New Mexico. Prairie Naturalist 26:183-186.

Robel, R. J., J. Harrington Jr, C. Hagen, J. Pitman, and R. Reker. 2004. Effect of energy development and human activity on the use of sand sagebrush habitat by lesser prairie-chickens in southwestern Kansas. Transactions of the North American Natural Resources Conference 69:251-266.

Robinson, S. G. 2015. Landscape ecology, survival and space use of lesser prairie-chickens. Thesis, Kansas State University, Manhattan, USA.

Robinson, S. G., D. A. Haukos, R. T. Plumb, J. D. Kraft, D. S. Sullins, J. M., Lautenbach, J. D. Lautenbach, B. K. Sandercock, C. A. Hagen, A. Bartuszevige, and M. A. Rice. 2018. Landscape characteristics linked to lesser prairie-chicken annual survival in Kansas. American Midland Naturalist 180:66-86.

Robinson, S. G., D. A. Haukos, R. T. Plumb, J. M., Lautenbach, D. S. Sullins, J. D. Kraft, J. D. Lautenbach, C. A. Hagen, and J. C. Pitman. 2017. Nonbreeding home range size and survival of lesser prairie-chickens. Journal of Wildlife Management 82:413-423.

Rodgers, R. D. 2016. A history of lesser prairie-chickens. Pages 15-38 in D. A. Haukos and C. W. Boal, editors. Ecology and conservation of lesser prairie-chickens. Studies in Avian Biology. CRC Press, Boca Raton, Florida, USA.

Ross, B. E., D. A. Haukos, C. A. Hagen, and J. C. Pitman. 2016. Landscape composition creates a threshold influencing lesser prairie-chicken population resilience to extreme drought. Global Ecology and Conservation 6:179-188.

Sawyer, H., R. M. Nielson, F. Lindzey, and L. L. McDonald. 2006. Winter habitat selection of mule deer before and during development of a natural gas field. Journal of Wildlife Management 70:396-403.

Schroeder, M. A., and C. E. Braun. 1991. Walk-in traps for capturing greater prairie-chickens on leks. Journal of Field Ornithology 62:378-385.
Silvy, N., M. Morrow, E. Shanley, and R. Slack. 1990. An improved drop net for capturing wildlife. Proceedings of the Southeastern Association of Fish and Wildlife Agencies 44:374-378.

Spencer, D., D. Haukos, C. Hagen, M. Daniels, and D. Goodin. 2017. Conservation reserve program mitigates grassland loss in the lesser prairiechicken range in Kansas. Global Ecology and Conservation 9:21-38.

Tyler, N., K. Stokkan, C. Hogg, C. Nellemann, A. Vistnes, and G. Jeffery. 2014. Ultraviolet vision and avoidance of powerlines in birds and mammals. Conservation Biology 28:630-632.

U.S. Geological Survey [USGS]. 2015. National elevation dataset. https:// lta.cr.usgs.gov/NED. Accessed 1 Sep 2017.

Van Pelt, W. E. 2016. Legal status of the lesser prairie-chicken. Pages 39-48 in D. A. Haukos and C. W. Boal, editors. Ecology and conservation of lesser prairie-chickens. Studies in Avian Biology. CRC Press, Boca Raton, Florida, USA.

Walker, B. L., D. E. Naugle, and K. E. Doherty. 2007. Greater sage-grouse population response to energy development and habitat loss. Journal of Wildlife Management 71:2644-2654.

Walter, W. D., J. W. Fischer, S. Baruch-Mordo, and K. C. Vercauteren. 2011. What is the proper method to delineate home range of an animal using today's advanced GPS telemetry systems: the initial step. U.S. Department of Agriculture National Wildlife Research Center - Staff Publications, paper 1375, Lincoln, Nebraska, USA.

Walters, K., K. Kosciuch, and J. Jones. 2014. Can the effect of tall structures on birds be isolated from other aspects of development? Wildlife Society Bulletin 38:250-256.

Wand, M. P., and M. C. Jones. 1995. Kernel smoothing. Monographs on Statistics and Applied Probability 60. CRC Press, Boca Raton, Florida, USA.

Wegge, P., M. H. Finne, and J. Rolstad. 2007. GPS satellite telemetry provides new insight into capercaillie Tetrao urogallus brood movements. Wildlife Biology 13:8-94.

Winder, V. L., K. M. Carrlson, A. J. Gregory, C. A. Hagen, D. A. Haukos, D. C. Kesler, L. C. Larsson, T. W. Matthews, L. B. McNew, M. A. Patten, J. C. Pitman, L. A. Powell, J. A. Smith, T. Thompson, D. H. Wolfe, and B. K. Sandercock. 2015. Factors affecting female space use in ten populations of prairie chickens. Ecosphere 6(9):166.

Winder, V. L., L. B. McNew, A. J. Gregory, L. M. Hunt, S. M. Wisely, and B. K. Sandercock. 2014. Space use by female greater prairie-chickens in response to wind energy development. Ecosphere 5(1):art3.

Winder, V. L., L. B. McNew, J. C. Pitman, and B. K. Sandercock. 2017. Effects of rangeland management on survival of female greater prairiechickens. Journal of Wildlife Management 82:113-122

Wolfe, D. H., M. A. Patten, E. Shochat, C. L. Pruett, and S. K. Sherrod. 2007. Causes and patterns of mortality in lesser prairie-chickens Tympanuchus pallidicinctus and implications for management. Wildlife Biology 13(Supp 1):95-104.

Associate Editor: Timothy Fulbright. 